DOI: 10.34015/2523-4552.2019.3.12

УдК 342.95

Шкарупа К. В., кандидат юридичних наук, викладач відділу підвищення кваліфікації прокурорів з нагляду за додержанням законів при виконанні судових рішень у кримінальних провадженнях Національної академії прокуратури України

e-mail: kvsh12@ukr.net

ORCID ID: 0000-0002-1816-3559

\title{
ОСОБЛИВОСТІ ПРЕВЕНТИВНОЇ ДІЯЛЬНІСТЬ НАЦІОНАЛЬНОЇ ПОЛІЦІЇ УКРАЇНИ
}

У статті запропоновано підходи щодо визначення поняття та сутності превентивної діяльності Національної поліції України. Розкрито завдання та функції превентивної діяльності Національної поліції України. 3'ясовано, що удосконалення превентивної діяльності органів поліції є частиною розвитку правоохоронних органів нашої держави загалом, та полягає в необхідності оновлення механізму правового регулювання в цілому й адміністративноправового зокрема, а також поетапному створенні системи управління в галузі роботи правоохоронних органів.

Ключові слова: профілактичні заходи; Національна поліція України; держава; правопорушення.

В статье предложены подходы к определению понятия и сущности превентивной деятельности Национальной полиции Украины. Раскрыто задачи и функции превентивной деятельности Национальной полиции Украины. Выяснено, что усовершенствование превентивной деятельности органов полиции является частью развития правоохранительных органов государства в целом, и заключается в необходимости обновления механизма правового регулирования в целом и административно-правового частности, а также поэтапном создании системы управления в области работы правоохранительных органов.

Ключевые слова: профилактические мероприятия; Национальная полиция Украина; государство; правонарушения.

Постановка проблеми. Одним із повноважень поліції $є$ профілактика (превенція) правопорушень, що полягає в цілеспрямованій діяльності підрозділів і служб поліції 3 метою виявлення, усунення i зниження негативного впливу чинників, що зумовлюють учинення кримінальних і адміністративних правопорушень, формування позитивного середовища соціалізації й коригування поведінки осіб, схильних до вчинення правопорушень. 
На думку переважної більшості правознавців, стратегічним напрямом еволюції органів правопорядку $\epsilon$ перехід від реактивного способу впливу на злочинність і ствердження концепції проактивної діяльності. Вона передбачає відхід від репресивної інтервенційної державної політики у правоохоронній сфері, визнання особливої соціальної значущості проблеми протидії правопорушенням, налагодження тісної взаємодії державних і комунальних суб'єктів поліцейської діяльності 3 інститутами громадянського суспільства у здійсненні роз'яснювальнопревентивної діяльності для коригування деструктивної поведінки окремих громадян й усунення чинників, що детермінують правопорушення [1].

Аналіз останніх досліджень і публікацій. Загальнотеоретичним аспектам адміністративно-правового статусу поліції України присвячено праці таких учених-адміністративістів як О. М. Бандурка, О. І. Безпалова, С. М. Гусаров, О.С. Доценко, $\begin{array}{ll}\text { Д. П. Калаянов, } & \text { В. В. Конопльов, }\end{array}$ О. В. Кузьменко, $\quad$ Є. В.Курінний, О. В. Негодченко, А. В. Панчишин, К. М. Рудой, Ю. В. Сіроштан та ін.

Постановка завдання. Метою статті $\boldsymbol{\epsilon}$ аналіз основних наукових поглядів на превентивну діяльність Національної поліції, з метою визначення основних проблем та пропозиції щодо удосконалення такої діяльності.

Виклад основного матеріалу. Превентивну діяльність здійснюють підрозділи Управління превентивної діяльності. Головного управління Національної поліції України в областях. Превентивна діяльність поліцейських органів Національної поліції України регламентується низкою нормативно-правових актів, зокрема: 1) Законами України «Конституція України», «Про Національну поліцію України», «Кодексу цивільного захисту України» та ін.; 2) Постановами Кабінету Міністрів України - «Положення про Національну поліцію»; «Положення про єдину державну систему запобігання, реагування і припинення терористичних актів та мінімізації їх наслідків» та ін.; 3) наказами МBC України - «Положення про Департамент превентивної діяльності Національної поліції України»; «Інструкція про порядок взаємодії територіальних органів поліції та міжрегіональних територіальних органів Національної поліції України під час реагування на надзвичайні ситуації, у випадку уведення правового режиму воєнного чи надзвичайного стан» та ін.

Як зазначають вітчизняні дослідники (О. М. Бандурка, О. І. Безпалова, О. В. Джафарова та ін.), «превентивні поліцейські заходи - це дія або комплекс дій, що обмежують певні права і свободи людини, використання яких не завжди пов'язане $з$ протиправною поведінкою конкретних осіб, застосовуються відповідно до закону для забезпечення виконання покладених на поліцію повноважень із дотриманням встановлених законом вимог» [2].

Профілактика правопорушень здійснюється в рамках адміністративної діяльності поліції - підзаконної, цілеспрямованої виконавчо-розпорядчої діяльності уповноважених суб'єктів з організації та здійснення охорони публічного порядку, забезпечення публічної безпеки, запобігання адміністративним і криміна- 
льним правопорушенням i припинення їх [3].

Превентивна діяльність здійснюється поліцейськими в процесі профілактики та запобігання вчиненню правопорушень, в ході реалізації профілактичного контролю стосовно додержання вимог законів та інших нормативно-правових актів щодо дітей, забезпечення безпеки дорожнього руху, охорони прав і свобод людини, інтересів суспільства й держави, протидії злочинності, організації роботи дозвільної системи, запобігання та припинення насильства в сім'ї тощо.

Для більш детального аналізу превентивної діяльності Національної поліції України та вироблення пропозицій для покращення такої діяльності необхідно звернутись до найкращих та найефективніших практик запобігання злочинності у таких країнах, як ФРН й Франція, в яких склалися вже усталені традиції взаємодії поліції й органів державної влади 3 місцевим населенням, що закріплені в окремо розроблених профілактичних програмах національного та місцевого рівнів.

У ФРН на початку 90-х років XX ст. були створені ради із запобігання злочинності як на рівні земель так і муніципалітетів. Всього держава налічує близько 2 тис. різних за призначенням та масштабом функціонування органів запобігання злочинності. Основні з них здійснюють свою діяльність на рівні земель, розглядаючи злочинність місцевим явищем. При цьому Федеральний уряд проводить загальнодержавну політику контролю злочинності [4].

$\mathrm{y}$ західній поліцеїстиці утвердилася думка щодо доцільності розгляду поліції насамперед як «суспі- льної служби, що діє в рамках своєї юрисдикції для підтримання публічного порядку та безпеки» [5]. Фахівці в галузі поліцейського права наголошують, що основні цілі поліції в демократичній державі полягають у такому: підтримання спокою й порядку в суспільстві; охорона та дотримання особистих основоположних прав і свобод, передбачених у європейських конвенціях про права людини; протидія та боротьба зі злочинністю; викриття злочинів; реалізація сервісної функції щодо суспільства передбачає охорону прав людини в такий спосіб, аби забезпечити місцевій територіальній громаді відчуття особистої безпеки та спокою [6].

Як бачимо, питанням безпеки саме територіальної громади приділяється значна увага в різних напрямах діяльності поліції, і превентивна діяльність не $\epsilon$ виключенням, у зв'язку з цим взаємодія територіальної громади з поліцією набуває важливого значення. Поряд з цим, зростає важливість оцінки діяльності поліції саме територіальною громадою.

Так, А. П. Титаренко, розглядаючи питання реалізації законодавчого принципу забезпечення суспільної довіри до поліції при здійсненні їі професійної діяльності, дійшов висновку, що «ефективність профілактичної діяльності - це співвідношення витрат на проведення превентивних заходів з отриманими результатами, то довіру суспільства до поліції слід розглядати як фактор, що значно знижує матеріальні, технічні, психологічні та інші витрати в боротьбі зі злочинністю. 3 точки зору значущості розглянутого принципу для результативності профілактичної 
діяльності працівника поліції цілком природно, що чим вище ступінь довіри у населення до працівників поліції, тим вища ефективність профілактики злочинів та правопорушень» [7].

Окремим аспектом ефективної діяльності поліції слід визначити саме ступінь довіри населення, а саме населення певної територіальної громади. У зв'язку з тим, що діяльність поліції $€$ відкритою, її можна прирівняти до діяльності обраної публічної адміністрації, а отже наслідками втрати довіри повинна стати зміна керівництва поліції.

Як стверджує В. І. Фелик, в науковій літературі не надано узагальненого тлумачення щодо поняття функцій профілактики правопорушень, але автор вважає, що функціями профілактичної діяльності Національної поліції можуть бути: 1) стратегічне та поточне планування профілактики правопорушень; 2) виявлення проблемних аспектів профілактичної діяльності та розробки заходів щодо їх усунення; 3) виявлення осіб, схильних до девіантної поведінки, зокрема шляхом тісної співпраці зі шкільними та іншими закладами освіти, органами опіки та піклування, громадськими формуваннями, підприємствами, установами, організаціями тощо; 4) проведення роз'яснювальної роботи з особами, схильними до девіантної поведінки, застосування інших методів профілактичного впливу; 5) збір, обробка, узагальнення та аналіз статистичних даних щодо вжитих профілактичних заходів та рівня їх результативності [8].

А. А. Трофімчук до основних видів профілактики правопорушень відносить профілактику випере- дження, спрямовану на попередження виникнення протиправних явищ i процесів у суспільному житті; профілактику обмеження, що перешкоджає поширенню протиправних об'єктів на тих чи інших рівнях суспільства, детермінації окремих видів правопорушень та формуванню типових рис різних категорій правопорушників; профілактику усунення таку діяльність суб'єктів, яка зменшує протиправні об'єкти і попереджує нову активізацію їхньої дії; профілактику захисту - сукупність заходів, що здійснюються 3 метою ліквідації умов, які сприяють вчиненню правопорушень [9].

Отже, зважаючи на важливість функції профілактики правопорушень в діяльності Національної поліції, а також відсутність чіткої регламентації на нормативному рівні критеріїв оцінки такої діяльності вбачається необхідним розробити та закріпити напрямки профілактичної роботи, критерії оцінки результатів та заходів реагування.

Наприклад, окремі вчені вважають, що удосконалення превентивної діяльності органів поліції $є$ частиною розвитку правоохоронних органів нашої держави загалом, та полягає в необхідності оновлення механізму правового регулювання в цілому й адміністративно-правового зокрема, а також поетапному створенні системи управління в галузі роботи правоохоронних органів, яка забезпечить становлення України як високорозвиненої європейської держави $з$ високим рівнем життя, соціальної стабільності, культури та демократії, а головним пріоритетом ї̈ діяльності буде служіння народу, національним інтересам, взаємодії 3 населенням країни тощо. Таким чи- 
ном, реформування правоохоронних органів, зокрема поліції:

- по-перше, має здійснюватися згідно з основними напрямами, визначеними концептуальними документами 3 проблем загальнодержавного реформування, та покликано забезпечити комплексний і поетапний підхід до розвитку цих органів на найближчу та віддалену перспективи;

- по-друге, реальні досягнення у формуванні напрямів оптимізації управлінської діяльності в системі правоохоронних органів (органів поліції) на регіональному рівні можуть бути отримані через структурну реорганізацію механізму управління, зміни функцій, компетенцій і методів діяльності структурних їх підрозділів, удосконалення організаційних основ функціонування механізму цих відомств, ефективної діяльності громадських інститутів у системі поліцейських органів [10].

I. С. Кравченко розглядав проблематику превентивної діяльності поліції, насамперед, через призму максимально наближених до її провадження підрозділів - патрульної поліції. Досить логічним $є$ висновок науковця про те, що удосконалення механізму застосування поліцейськими превентивних заходів, йде рука об руку із розвитком патрульної по- ліції загалом, та повинно здійснюватися за наступними напрямами: підвищення професійної організації діяльності патрульної поліції; удосконалення нормативно-правової основи діяльності Національної поліції України в цілому та патрульної поліції зокрема; забезпечення якісного відбору і навчання кадрів для патрульної служби [11].

Звичайно, висновок про необхідність удосконалення механізму застосування поліцейськими превентивних заходів, зважаючи на реформування системи МBC, і Національної поліції зокрема, заслуговує на увагу. Проте забезпечення якісного відбору й навчання кадрів ігнорується протягом тривалого часу, і вимагає не удосконалення, а вироблення концепції механізму добору, навчання та розподілу.

Висновки. Підсумовуючи викладені у статті наукові погляди на стан профілактичної діяльності Національної поліції України, слід зробити наступні висновки: чітко визначити проблемні аспекти профілактичної діяльності з метою своєчасного реагування та вжиття заходів; вироблення концепції механізму добору та навчання кадрів; розробка та закріплення критеріїв ефективності діяльності поліції; визначення поточних та кінцевих результатів профілактичної діяльності.

\section{Список використаних джерел}

1. Проневич О. С. Проактивна діяльність поліції (міліції) як складова сучасної парадигми охорони правопорядку. Форум права. Науковий журнал [електронне наукове фахове видання]. ХНУВС. 2011. № 3. С. 639-643.

2. Адміністративна діяльність поліції у питаннях та відповідях : навч. посіб. / за заг. ред. О. М. Бандурки ; О. І. Безпалова, О. В. Джафарова, С. М. Князєв, та ін.; передм. О. М. Бандурки ; МВС України, Харків. нац. ун-т внутр. справ. Харків, 2017. 242 с. 
3. Школа С. М. Правові засади профілактичної роботи національної поліції України. Актуальні проблеми вітчизняної юриспруденції. 2016. № 3. С. 129-132.

4. The European Crime Prevention Network (EUCPN). URL: https://eucpn.org/ (дата звернення: 10.09.2019).

5. Наилучшая практика построения партнерства между полицией и обществом [сост. Карти К.]. Вена : Организация по безопасности и сотрудничеству в Европе, 2008. $81 \mathrm{c}$.

6. Yach D. N. Revisiting Democratic Policing in Action. The Police Journal. 1999. № 10. P. 294-299.

7. Титаренко А.П. Общественное доверие к полиции как фактор, способствующий индивидуальной профилактической работе с гражданами. Вестник Томского государственного университета. 2015. № 393. С. 167-170.

8. Фелик В. І. Система функцій профілактичної діяльності Національної поліції України. Порівняльне аналітичне право. 2016. № 2. С. 156-158.

9. Трофімчук А. А. Профілактика адміністративних правопорушень у сфері виготовлення, гуртової та роздрібної торгівлі аудіовізуальною продукцією : автореф. дис. на здобуття наук. ступеня канд. юрид. наук : 12.00.07. Львів, 2009. 18 с.

10. Діденко М. Адміністративно-правові засади впровадження принципів публічної служби в діяльності органів внутрішніх справ України. Державне управління та місцеве самоврядування: Збірник наукових праць. 2009. Вип.1 (1). С. 5-11.

11. Кравченко I. С. Актуальні проблеми діяльності патрульної служби Національної поліції України. Науковий вісник Ужгородського національного університету. 2016. Випуск 39. Том 1. С. 139-142.

\section{References}

1. Pronevich, O. S. (2011). Proaktivna diyalnist policiyi (miliciyi) yak skladova suchasnoyi paradigmi ohoroni pravoporyadku. Forum prava. Naukovij zhurnal, 3, 639-643 [in Ukrainian].

2. Bandurka, O. M. (Red.). (2017). Administrativna diyalnist policiyi u pitannyah ta vidpovidyah. Harkiv, Harkiv. nac. un-t vnutr. sprav [in Ukrainian].

3. Shkola, S. M. (2016). Pravovi zasadi profilaktichnoyi roboti nacionalnoyi policiyi Ukrayini. Aktualni problemi vitchiznyanoyi yurisprudenciyi, 3, 129-132 [in Ukrainian].

4. The European Crime Prevention Network (EUCPN). URL: https://eucpn.org/ (data zvernennya: 10.09.2019).

5. Karti, K. (sost.). (2008) Nailuchshaya praktika postroeniya partnerstva mezhdu policiej i obshestvom. Vena : Organizaciya po bezopasnosti i sotrudnichestvu v Evrope [in Russian].

6. Yach, D. N. (1999). Revisiting Democratic Policing in Action. The Police Journal, 10, 294-299.

7. Titarenko, A. P. (2015). Obshestvennoe doverie $\mathrm{k}$ policii kak faktor, sposobstvuyushij individualnoj profilakticheskoj rabote s grazhdanami. Vestnik Tomskogo gosudarstvennogo universiteta, 393, 167-170 [in Russian].

8. Felik, V. I. (2016). Sistema funkcij profilaktichnoyi diyalnosti Nacionalnoyi policiyi Ukrayini. Porivnyalne analitichne pravo, 2, 156-158 [in Ukrainian].

9. Trofimchuk, A. A. (2009). Profilaktika administrativnih pravoporushen u sferi vigotovlennya, gurtovoyi ta rozdribnoyi torgivli audiovizualnoyu produkciyeyu. (Avtoref. dis. na zdobuttya nauk. stupenya kand. yurid. nauk). Lviv [in Ukrainian].

10. Didenko, M. (2009). Administrativno-pravovi zasadi vprovadzhennya principiv publichnoyi sluzhbi v diyalnosti organiv vnutrishnih sprav Ukrayini. Derzhavne upravlinnya ta misceve samovryaduvannya: Zbirnik naukovih prac, 1(1), 5-11 [in Ukrainian]. 
11. Kravchenko, I. S. (2016). Aktualni problemi diyalnosti patrulnoyi sluzhbi Nacionalnoyi policiyi Ukrayini. Naukovij visnik Uzhgorodskogo nacionalnogo universitetu, 39(1), 139-142 [in Ukrainian].

K. Shkarupa, PhD in Law, Lecturer of the Department of public prosecutors training in supervision over laws observance in the enforcement of court judgments delivered in criminal cases at National Prosecution Academy of Ukraine

e-mail: kvsh12@ukr.net; ORCID ID: 0000-0002-1816-3559

\section{Peculiarities of preventive activities of the National Police of Ukraine}

The article identifies the main approaches to defining the concept and nature of preventive activity of the National Police of Ukraine. The tasks and functions of preventive activity of the National Police of Ukraine are revealed.

It is emphasized that the issue of the security of the local community itself is receiving considerable attention in various areas of police activity, and preventive action is no exception, therefore the interaction of the local community with the police is of great importance. At the same time, the importance of evaluating police activity by the territorial community is growing.

It has been found out that improvement of preventive activity of police bodies is a part of development of law enforcement agencies of our country in general, and it is necessary to update the mechanism of legal regulation in general and administrative and legal in particular, as well as the gradual creation of a system of management in the field of law enforcement agencies, which will ensure the establishment Ukraine as a highly developed European country with high standard of living, social stability, culture and democracy, and its main priority will be to serve I am the people's national interests, interaction with the population of the country and so on.

It is determined that the functions of preventive activity of the National Police may be: strategic and current planning of prevention of offenses; identification of problematic aspects of prevention activities and development of measures for their elimination; identifying persons who are prone to deviant behavior, in particular by working closely with school and other educational institutions, guardianships, community organizations, businesses, institutions, organizations, etc.; providing explanatory work to persons who are prone to deviant behavior, applying other methods of preventive influence; collecting, processing, summarizing and analyzing statistics on the preventive measures taken and the level of their effectiveness.

Keywords: preventive measures; National Police of Ukraine; state; offenses. 